Open Access

\title{
University students' self-regulated learning using digital technologies
}

\author{
Carmen Yot-Domínguez and Carlos Marcelo * (D)
}

\footnotetext{
* Correspondence: marcelo@us.es Universidad de Sevilla, Pirotecnia s/n C.P, 41013 Sevilla, Spain
}

\begin{abstract}
Analysing the process by which students - whether at university or not-manage and facilitate their own learning has been a recurrent educational research problem. Recently, the question arises about how the development of strategies taking place during the aforementioned process could be made easier by using technologies. In an effort to know whether university students really use digital technologies to plan, organize and facilitate their own learning, we have proposed three research questions. Which technologies do university students use to self-regulate their learning? What self-regulated learning strategies do they develop using technologies? What profiles could be identified among students based on their use of self-regulation strategies with technology? To answer these questions, the "Survey of Self-regulated Learning with Technology at the University" was designed. Information from a sample group with 711 students from various universities located in the region of Andalusia (Spain) was collected with this survey. The results indicate that university students, even when they are frequent users of digital technology, they tend not to use these technologies to regulate their own learning process. Of all technologies analysed, Internet information search and instant communication tools are used continually. In turn, the most generalised self-regulation learning strategies are those relative to social support. Nevertheless, students differ from each other regarding their use and frequency. There are groups of students who make use of self-regulation strategies when learning with technologies. In this regard, two distinctive groups of students have been identified, who show differentiated selfregulated levels.
\end{abstract}

Keywords: Higher education, Self-regulated learning, Technology, Digital native

\section{Introduction}

Today, one of the most extended myths is that young people are regular and skilled in the use of digital technologies because they were born in the last two decades. Prensky's work (Prensky, 2001) is considered a classic as he coined the term "digital natives" to refer to a new generation that has grown up with technologies and for which the term "new" almost seems senseless.

Although refuted (Bennett et al., 2008), this idea continues to be present in our society. We assume that young people use and process technologies with greater ease than those known as "digital immigrants". Nevertheless, numerous studies (Jones et al., 2010; Kennedy et al., 2008) have proven that the "Net generation" is not consistent

(c) The Author(s). 2017 Open Access This article is distributed under the terms of the Creative Commons Attribution 4.0 International License (http://creativecommons.org/licenses/by/4.0/), which permits unrestricted use, distribution, and reproduction in any medium, provided you give appropriate credit to the original author(s) and the source, provide a link to the Creative Commons license, and indicate if changes were made. 
according to the technological knowledge that users have and the use they make of these technologies.

This research seeks to find out whether university students really use digital technologies to plan, organize and facilitate their own learning. We explore not only the type of technologies they use but also the learning strategies for which they are used. We are especially interested in independent and self-regulated learning strategies that students develop from their own educational learning process.

The self-regulated learning (SRL) concept arose in the 1980s as a research problem and, for decades, it has continued to be important for researchers and teachers (Zimmerman \& Schunk, 2011). One reason that explains the interest in SRL lies in the fact that we live in a society where life-long learning is increasingly important and informal learning environments requiring self-regulation skills proliferate (Beishuizen \& Steffens, 2011). The university is responsible for motivating students to continually want to learn more. Developing independent learners is also one of the objectives that university studies are currently pursuing. The importance of the matter is justified because academic success is influenced by the students' ability to learn independently of the support offered by instructors (Kingsbury, 2015).

SRL-related research explains the processes by which students take control of their own learning and the strategies they develop to favour this learning. One of the initial aspects that characterises SRL is that the learner begins his/her search based on personal initiative, perseverance and adaptive skills (Zimmerman, 2009). To learn, students use a variety of strategies to regulate certain cognitive, motivational and behavioural aspects as well as certain environmental characteristics (Pintrich, 1999a, b ; Zimmerman and Martinez Pons, 1986).

According to Zimmerman's (1998) cyclic model, within a social cognitive perspective, self-regulation is a self-directed learning process that occurs in three successive phases. These are forecast (processes that precede the learning effort), execution control (processes that occur during learning) and self-reflection (processes that occur after learning). During the initial phase, students approach the learning activity analysis; they assess their ability to successfully accomplish and establish goals and plans to complete the process (Panadero \& Alonso Tapia, 2014). During the second phase, the two main processes that students use are self-control and self-observation. Self-control involves a variety of strategies including self-instruction, seeking help or self-consequences (Dabbagh \& Kitsantas, 2013). Furthermore, self-observation (observation and performance follow-up and results) implies two types of actions: self-monitoring (comparison of the actions carried out or the resulting products with criteria that assess the quality of what is being undertaken) and self-recording (record of actions while being executed to promote in-depth review). Lastly, the self-reflection phase involves those processes that follow the learning effort. At this point, students judge their learning and draw up reasons to justify the results obtained. One way to do this is through self-assessments (Zimmerman \& Moylan, 2009).

Pintrich (2004) breaks down this central phase into two: forethought, planning, and activation (phase 1), monitoring (phase 2), control (phase 3 ) and reaction and reflection (phase 4). He completes his process model with another component that identifies the strategy types participating in the SRL. The SRL dimensions that arise are: metacognitive regulation (commitment with the learning goal, planning and follow-up), 
cognition regulation (use of cognitive strategies), motivation regulation (adjustment of mood, making learning attractive), behavioural regulation (time and effort management) and environmental regulation (seeking material and social resources). Motivational or volitional control strategies were studied independently (Pintrich, 1999) while the last two were considered, initially, under the same category (Pintrich, 1999a). The final version of the model contemplates the fourteen self-regulated learning strategies identified by Zimmerman \& Martinez Pons (1986).

Developing this self-regulation cycle could be facilitated by technologies. Kitsantas \& Dabbagh (2011) acknowledge that 2.0 social software technologies (communications tools, resource and experience exchange tools and social network tools) have ample potential to encourage self-regulation but empiric research in this area is still very limited. Kitsantas (2013) has described how certain technologies support each of the three phases presented above. This is carried out to orient teachers about how to facilitate self-regulation of learning.

Digital technologies represent an open gateway to new learning alternatives and options that favour the acquisition of self-regulation skills (Bernacki et al., 2011; Schneckenberg et al., 2011). At the same time, in technology-based learning experiences, using SRL is essential (Winters et al., 2008). The relation between SRL strategies and technologies may even be casual, as seen in the work by Valentín et al. (2013).

A number of studies have analysed the presence of technologies in the university student learning processes, either in formal or informal learning situations (Corrin et al., 2010; Margaryan et al., 2011). These help to determine which range of technologies are used but not which learning purposes are pursued with the use of each one. This is how Lai \& Gu (2011) adopted SRL as a theoretical framework for understanding how university students use technologies. These authors were concerned with the use of technology outside the classroom for self-regulating learning. They found, in line with the aforementioned studies, that students have limited knowledge regarding the use of technology for learning. Despite this fact, students selectively use a variety of technologies to self-regulate their learning.

However, after reviewing all these previous studies, we still know very little about technology mediated SRL processes undertaken by university students. This leads us to the following questions: Which technologies do university students use to self-regulate their learning? Which SRL strategies do they develop using technologies? What profiles could be identified among students based on their use of self-regulation strategies with technology?

\section{Method}

To respond to these questions, we have designed the Survey of Self-regulated Learning with Technology at the University (SRLTU). This survey incorporates some initial questions (sex, age, university where the students are studying and the degrees currently studied) and 33 items that refer to various SRL strategies that may be performed using technologies. These items were assessed on a scale of 1 (Never) to 5 (Always) depending on the frequency with which they are carried out. As shown in Table 1, we used these items to analyse the level at which the different SRL strategies were used, which corresponded to the phases control of execution and self-reflection. The items also facilitate the analysis of the type of technology students use to learn. 
Table 1. SRL strategies and technologies associated with SRLTU items. Classification of SRLTU items according to the Zimmerman and Pintrich models

\begin{tabular}{|c|c|c|c|c|}
\hline Technology & Items & Strategies & $\begin{array}{l}\text { Zimmerman } \\
(1989,1990)\end{array}$ & Pintrich, 1999a, b \\
\hline $\begin{array}{l}\text { 1. Communication Tools: WhatsApp, } \\
\text { Line, Skype, Google Talk. }\end{array}$ & 12,13 & $\begin{array}{l}\text { Exchange information } \\
\text { Solve doubts } \\
\text { Discussion }\end{array}$ & $\begin{array}{l}\text { Social } \\
\text { support }\end{array}$ & $\begin{array}{l}\text { Resource } \\
\text { Management } \\
\text { (Social) }\end{array}$ \\
\hline \multirow[t]{3}{*}{$\begin{array}{l}\text { 2. Repositories: Slideshare, Instagram, } \\
\text { Pinterest, Issuu, Calameo, Youtube, } \\
\text { iTunes, iVoox. }\end{array}$} & $\begin{array}{l}3,5,6 \\
20,21\end{array}$ & $\begin{array}{l}\text { Review of specific } \\
\text { material obtained } \\
\text { for studies }\end{array}$ & $\begin{array}{l}\text { Record } \\
\text { review }\end{array}$ & $\begin{array}{l}\text { Metacognitive } \\
\text { (Regulation) }\end{array}$ \\
\hline & 31 & Be informed & $\begin{array}{l}\text { Search for } \\
\text { information }\end{array}$ & $\begin{array}{l}\text { Metacognitive } \\
\text { (Planning) }\end{array}$ \\
\hline & $\begin{array}{l}15,28 \\
29\end{array}$ & $\begin{array}{l}\text { Share one's own } \\
\text { productions and } \\
\text { material }\end{array}$ & $\begin{array}{l}\text { Social } \\
\text { support }\end{array}$ & $\begin{array}{l}\text { Resource } \\
\text { Management } \\
\text { (Social) }\end{array}$ \\
\hline \multirow[t]{3}{*}{ 3. Social Networks: Twitter, Facebook. } & 1 & Comment information & $\begin{array}{l}\text { Organise and } \\
\text { transform }\end{array}$ & $\begin{array}{l}\text { Cognitive } \\
\text { (Formulation and } \\
\text { Organisation) }\end{array}$ \\
\hline & 18 & Information Exchange & $\begin{array}{l}\text { Social } \\
\text { support }\end{array}$ & $\begin{array}{l}\text { Resource } \\
\text { Management } \\
\text { (Social) }\end{array}$ \\
\hline & 17 & Be informed & $\begin{array}{l}\text { Search for } \\
\text { information }\end{array}$ & $\begin{array}{l}\text { Metacognitive } \\
\text { (Planning) }\end{array}$ \\
\hline \multirow[t]{3}{*}{$\begin{array}{l}\text { 4. Production and Storage Tools in the } \\
\text { cloud: wikis \& blogs, Dropbox, } \\
\text { Google }+ \text {. }\end{array}$} & 4,11 & Team work & $\begin{array}{l}\text { Social } \\
\text { support }\end{array}$ & $\begin{array}{l}\text { Resource } \\
\text { Management } \\
\text { (Social) }\end{array}$ \\
\hline & 14 & Comment information & $\begin{array}{l}\text { Organise and } \\
\text { transform }\end{array}$ & $\begin{array}{l}\text { Cognitive } \\
\text { (Formulation and } \\
\text { Organisation) }\end{array}$ \\
\hline & 33 & Be informed & $\begin{array}{l}\text { Search for } \\
\text { information }\end{array}$ & $\begin{array}{l}\text { Metacognitive } \\
\text { (Planning) }\end{array}$ \\
\hline 5. Social Markers \& RSS: Delicious, Sage. & 26,27 & $\begin{array}{l}\text { Record Information } \\
\text { Receive Information }\end{array}$ & $\begin{array}{l}\text { Search for } \\
\text { information }\end{array}$ & $\begin{array}{l}\text { Metacognitive } \\
\text { (Planning) }\end{array}$ \\
\hline \multirow[t]{3}{*}{ 6. Multimedia Resources: podcast, video. } & 2 & $\begin{array}{l}\text { Listen to the previously } \\
\text { recorded lesson }\end{array}$ & $\begin{array}{l}\text { Record } \\
\text { review }\end{array}$ & $\begin{array}{l}\text { Metacognitive } \\
\text { (Regulation) }\end{array}$ \\
\hline & 7 & Self-listening & Memorisation & Cognitive (Essay) \\
\hline & 22 & Self-observation & Save records & $\begin{array}{l}\text { Metacognitive } \\
\text { (Follow Up) }\end{array}$ \\
\hline $\begin{array}{l}\text { 7. Assessment Tools: ExamTime, Google } \\
\text { Application Forms. }\end{array}$ & 23,24 & Verify learning & $\begin{array}{l}\text { Self- } \\
\text { Assessment }\end{array}$ & $\begin{array}{l}\text { Metacognitive } \\
\text { (Follow Up) }\end{array}$ \\
\hline \multirow[t]{2}{*}{$\begin{array}{l}\text { 8. Internet: Wikipedia or online } \\
\text { dictionaries; translators; Google } \\
\text { academic, Dialnet. }\end{array}$} & 9 & Translate information & $\begin{array}{l}\text { Organise and } \\
\text { Transform }\end{array}$ & $\begin{array}{l}\text { Cognitive } \\
\text { (Formulation and } \\
\text { Organisation) }\end{array}$ \\
\hline & 8,32 & Locate information & $\begin{array}{l}\text { Search for } \\
\text { information }\end{array}$ & $\begin{array}{l}\text { Metacognitive } \\
\text { Planning) }\end{array}$ \\
\hline $\begin{array}{l}\text { 9. Management tools: Cmap, } \\
\text { MindManager; RefWorks, Mendeley; } \\
\text { Viper. }\end{array}$ & $\begin{array}{l}10,16 \\
25\end{array}$ & $\begin{array}{l}\text { Create concept maps, } \\
\text { Draft texts managing } \\
\text { bibliography } \\
\text { Draft texts and verify } \\
\text { plagiarism }\end{array}$ & $\begin{array}{l}\text { Organise and } \\
\text { Transform }\end{array}$ & $\begin{array}{l}\text { Cognitive } \\
\text { (Formulation and } \\
\text { Organisation) }\end{array}$ \\
\hline \multirow{2}{*}{$\begin{array}{l}\text { 10. Other Technology: specific apps } \\
\text { (Kalkulilo, Whiteboard Lite) \& } \\
\text { organisers (Google Calendar, } \\
\text { EverNote). }\end{array}$} & 30 & $\begin{array}{l}\text { Resolve academic } \\
\text { activities making them } \\
\text { more attractive }\end{array}$ & & $\begin{array}{l}\text { Volitional } \\
\text { verification (Task } \\
\text { Verification) }\end{array}$ \\
\hline & 19 & $\begin{array}{l}\text { Manage academic } \\
\text { activities }\end{array}$ & $\begin{array}{l}\text { Establish } \\
\text { goals and plan }\end{array}$ & $\begin{array}{l}\text { Resource } \\
\text { Management (Time } \\
\text { and Effort) }\end{array}$ \\
\hline
\end{tabular}


The research team collected the learning strategies that young people could independently develop with the various technologies currently available to them. Within a week, each member was responsible for reviewing the statement for the various strategies suggested and to determine whether or not this extensively addressed the objective of the study. All contributions made were taken into consideration. When the final draft of the strategies was ready, the self-regulating learning models of Zimmerman and Pintrich were used (because these have been widely recognized and both are very similar when explaining self-regulated learning) to confirm that these were pertinent and diversified. Likewise, it was verified that all of them could analyse the use of the different digital technologies. That is why the technologies mentioned in the different strategies were identified and classified in categories.

Once the survey was drafted, it was validated by a group of eight university students. Later, it was developed using the online e-survey service and distributed to the university teachers from ten universities in Andalusia. These teachers were asked to inform their students about the survey.

The quantitative data that we collected was analysed using SPSS statistical software. Esurvey generates an Excel spread sheet with all the cases and answers for each variable. Any errors contained were corrected before importing the information to SPSS to work with it. Essentially, the numerous response intents that did not materialize were eliminated.

In order to measure the survey's reliability, a Cronbach's Alfa coefficient was calculated. The internal consistency was .877 .

According to the first research problem, this study is interested in gathering information about the digital technologies that university students use for independent learning. Thus, we began by identifying the many digital technologies available to any of the students mentioned in the SRLTU. These technologies were grouped into the ten categories indicated in Table 1. Then, the average frequency of use of each was calculated.

Our next interest focused on how students use technologies to support their learning strategies. To answer this question, we performed a factor analysis of the 33 survey items. In keeping with Bartlett's test $(p=.000)$ and the Kaiser-Meyer-Olkin index ( 886$)$, the data was adjusted for the application of the factor analysis. A varimax rotation was used to analyse the principal components. This exploratory analysis determined that the number of factors should be 9 , and would therefore explain a variation of $54.904 \%$ of the data. To shape the factors, factorial loads greater than 0.40 were considered. Then, the mean and standard deviation were calculated for each factor. Descriptive statistics were also used to individually interpret the level of use for the items.

Lastly, we wanted to delve into the possibilities of identifying differentiated university student profiles based on the SRL strategies they develop with digital technologies. Other studies have identified student profiles based on their use of technologies (Lorenzo Romero et al., 2014) and the self-regulation learning skills they have (Barnard Brak et al., 2010; Ning \& Downing, 2015; Valle et al., 2008.

For this, a cluster analysis was carried out based on the frequency with which the students made use of each factor. First, a hierarchy analysis was performed with the nearest neighbour method to detect outliers. Three participants were withdrawn from the analysis as they were atypical cases. Then, following the Ward method, we determined that the number of conglomerates should be 4 . Lastly, a $k$-means analysis was performed considering the identified number. In the results, reference is made only to the two conglomerates of students with the greatest difference between them. 


\section{Sample}

The sample was made up by 711 university students from the various universities located in the region of Andalusia (Spain). Of these, 38.3\% were male and 61.2\% female, and $59.8 \%$ of the participants were between 21 and 25 years of age while $27 \%$ were under 21 .

The university students belonged to various Andalusian universities. Forty three percent of the participants were from the University of Seville, $18.7 \%$ from the University of Granada, $12 \%$ from the University of Cordoba and 11.5\% from the University of Cadiz. A lower percentage was associated with the Universities of Malaga (0.1\%) Almeria (0.7\%), Jaen (3.2\%), Pablo de Olavide (Seville) (3.2\%) and Huelva (6.5\%). The students were from several fields: $51.2 \%$ were studying social sciences, $18.6 \%$ engineering and architecture, $13.5 \%$ health sciences and $11.7 \%$ science. Only $4.5 \%$ of the students were from the field of arts and humanities.

\section{Results}

\section{Which technologies do university students use to self-regulate their learning?}

As shown in Fig. 1, it can be stated that students do use digital technologies in SRL, but their use is limited.

Of all technologies, only three of these reached an average level of use $(2.5 \leq M \geq 3.5)$. These were: tools to search for information on Internet such as search engines or data

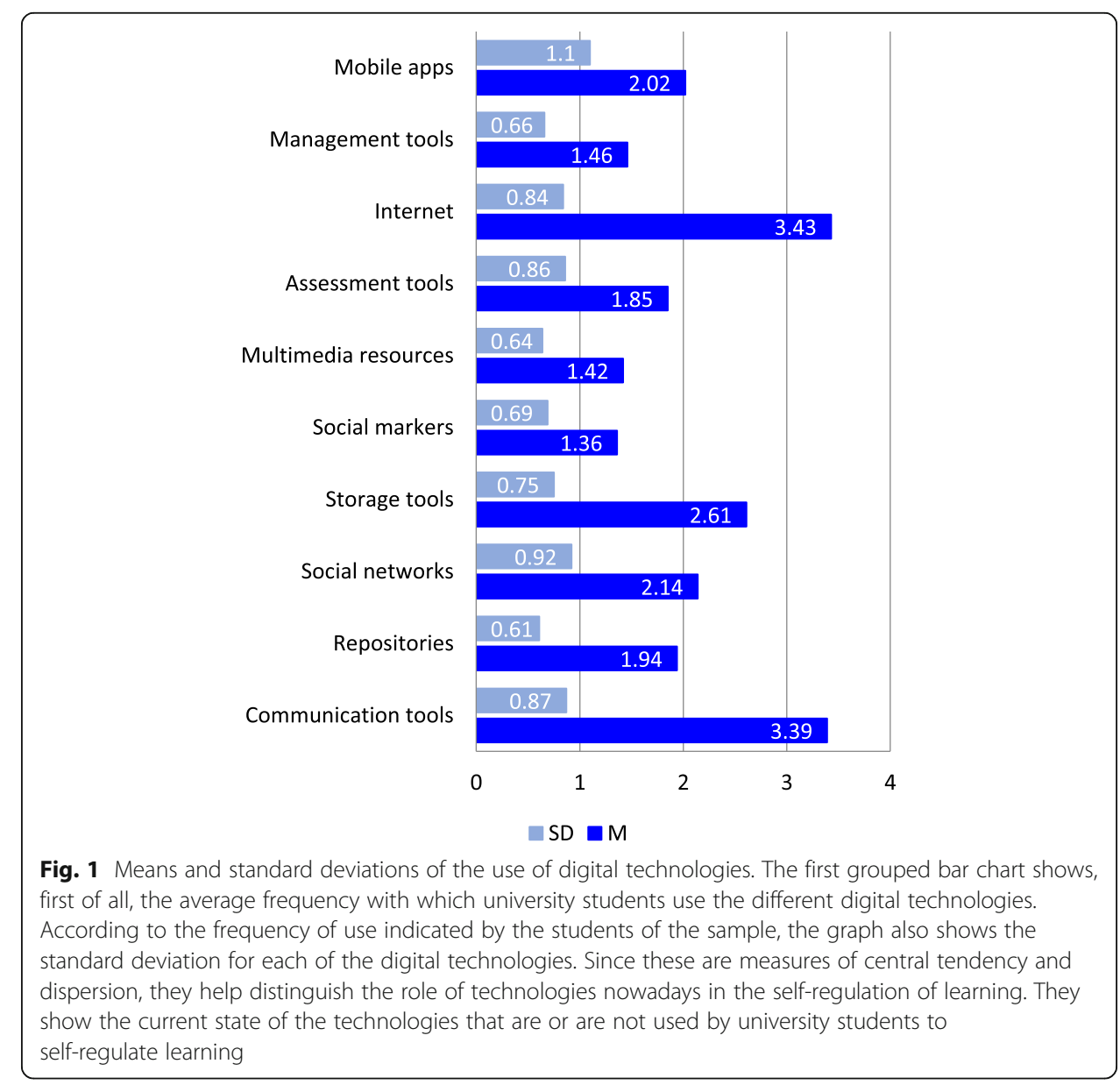


bases $(M=3.43 \mathrm{SD}=.84)$, communication tools such as WhatsApp or Google Talk $(M=3.39 \mathrm{SD}=.87)$ and 2.0 production and cloud storage tools such as wikis or Google + $(M=2.61 \mathrm{SD}=.75)$. However, these fail to have the same degree of penetration in the students' study routine. More than $60 \%$ of the students use the first two to some degree, although in most cases it is only occasional use $(42.8 \%, 50.4 \%)$. Less than $40 \%$ use production and cloud storage tools with some frequency. Our results coincide with those of other researchers (Gallardo et al., 2015; Kennedy et al., 2008; Margaryan et al., 2011). Web search tools and instant messaging are among the most frequently used technologies for informal learning situations or university academic life.

Regarding all other digital technologies, the degree to which these are used is low or very low $(\mathrm{M} \leq 2.5)$. Among the less used are social markers and Really Simple Syndication (RSS) feeds $(M=1.36 \mathrm{SD}=.69)$. Seventy percent of the students have never used them. Multimedia resources (podcasts and videos), management tools (concept map creation and literature management or plagiarism verification) or repositories (videos, images, podcasts, presentations or learning objects) are not used for SRL support either. The same holds true for assessment tools, social networks, professional apps and personal organisers.

In line with previous studies, our results show that university students are not inclined to using technologies when regulating their own learning process, even when they are regular users of digital technologies for social, personal and leisure activities, among others. In part, this is explained by their limited view that technologies have in learning. Although students know how to use technologies, they are lacking in how to efficiently use them to support their own learning process (Littlejohn et al., 2010).

When focusing on social networks, these have a low level of use. According to Gosper et al. (2013), students frequently use this technology in every-day life. However, they are unwilling to use it for learning as it is not perceived as a tool with a high educational potential. Email is perceived as more efficient when solving academic issues (Vrocharidou \& Efthymiou, 2012); therefore, it is used more often (Dahlstrom et al., 2013). Social applications, such as Facebook, are relegated almost exclusively to non-academic purposes (Swanson \& Walker, 2015).

For students to further adopt digital technologies that favour their own learning, they need information about how to use them, even when their degree of digital competence is high (Deepwell \& Malik, 2008). As set forth by Lai et al. (2012), support, advice and motivation from teachers becomes crucial.

\section{What SRL strategies do university students develop using technologies?}

Each of the resulting factors is described herein, focusing on the degree to which students use the various SRL strategies.

Factor 1. Share information. In the first factor, we located SRL strategies that belong to several of the categories considered in the models by Zimmerman and Pintrich (see Table 1). The items are characterised by the students' concern about broadcasting and sharing the documents that they draw up for class. These documents may have varied formats, such as presentations, books, blogs or electronic addresses. When deciding to share digital resources, students show a high degree of self-regulation, as by broadcasting their work, they run the "risk" of others 
criticizing their work. This is especially clear when students use blogs to express their opinions and where anyone may make a comment. In this sense, our results are coherent with those of Baggetun \& Wasson (2006) when analysing the contribution of blogs to SRL. They pointed out that the nature of an open, written environment forces the recognition that SRL is not limited to the individual sphere, it also acquires collectively (collective self-regulation).

The factor "frequency of use" was very low $(\mathrm{M}=1.37 \mathrm{SD}=.57)$ among the students: $87.1 \%$ of the students had never used social markers to store and share information, 86.5\% had never had a blog to publish considerations and $82.1 \%$ had never made their work available to others by means of an electronic format for reuse (Table 2).

Factor 2. Active presence. The second factor is linked to strategies in which the learning objectives are sought through an active presence on the web. Not only is the web an extensive library to search for information, it is also a space for interaction to construct social learning. Social networks as well as micro blogging services have proven to be a new means of communication that supports informal learning (Ebner et al., 2010; Vivian, 2011). Students use these resources to discuss topics they are studying, exams and assessments, share information, ideas, feelings and opinions or exchange study resources (texts, photos, videos). Such resources favour reflective thoughts, collaborative learning, the reception of feedback and coaching from others (Gao et al., 2012; Nosko \& Wood, 2011). Their contribution is not only limited to academic development; it is also useful for personal, social and professional development (Wong et al., 2012).

As shown in Table 3, university students use digital technologies very little to promote their presence before others $(M=2.08 \mathrm{SD}=.86)$. Nevertheless, from the set of strategies, one is implemented more often than the rest. This is the case because $29.9 \%$ of the students regularly consult updates relative to study contents distributed via social networks. Of these, $11.3 \%$ do it more frequently.

Factor 3. Documentation and classification. Searching for and classifying information is an essential aspect of university work. Today's students are ever more accustomed to using specific tools that help them to locate, organize and recover the information they need. This is not the case when it comes to relying upon these tools to manage and correctly use the sources in their academic work (He et al., 2012). Students prefer digital documents available online. Students see Internet, and more specifically search engines and academic databases, as the starting point when it comes to searching for information (Dilek-Kayaoglu, 2014). However, they need further information about how

Table 2 Factorial loads, means and standard deviations of SRLTU items for the first factor, "Share information"

\begin{tabular}{|c|c|c|c|}
\hline & Factorial load & M & SD \\
\hline $\begin{array}{l}\text { 28. When designing a multimedia presentation, I share it through repositories } \\
\text { such as Slideshare. }\end{array}$ & .754 & 1.53 & .99 \\
\hline $\begin{array}{l}\text { 29. I turn my work and notes into an e-book (Issuu, Calameo...) to facilitate its } \\
\text { distribution. }\end{array}$ & 659 & 1.32 & .83 \\
\hline 26. I use social markers to register information found on Internet. & 619 & 1.20 & .63 \\
\hline 14. I have a blog where I comment topics regarding contents. & .598 & 1.24 & .72 \\
\hline 25. Before turning in my work, I verify its originality using anti-plagiarism software. & .544 & 1.39 & .90 \\
\hline 10. When studying, I create concept maps with specific software. & .451 & 1.54 & .98 \\
\hline
\end{tabular}


Table 3 Factorial loads, means and standard deviations of SRLTU items for the second factor, "Active presence"

\begin{tabular}{|c|c|c|c|}
\hline & Factorial load & M & SD \\
\hline $\begin{array}{l}\text { 18. I'm a member of groups on social networks that discuss, exchange information, } \\
\text { etc., about content-related topics. }\end{array}$ & .739 & 2.13 & 1.36 \\
\hline 17. I look up content-related information, news, etc., distributed on social networks. & .679 & 2.68 & 1.32 \\
\hline $\begin{array}{l}\text { 15. I share pictures on Instagram, Pinterest... about practical work carried out for } \\
\text { the subjects. }\end{array}$ & .544 & 1.93 & 1.18 \\
\hline $\begin{array}{l}\text { 1. I discuss the information facilitated by teachers during class using Twitter, } \\
\text { Facebook... }\end{array}$ & .487 & 1.62 & .98 \\
\hline
\end{tabular}

to correctly cite and reference these sources (Imler \& Hall, 2009). Our results prove this, as $40.1 \%$ of the students search for information in databases with high or very high frequency. Yet, with the same frequency, only $7.2 \%$ store and classify such sources using citation management tools and recover the information when producing reports, essays, etc (Table 4).

Factor 4. Superficial use with limited information processing. Students resort to online encyclopaedias and dictionaries, as opposed to hard copies, when faced with the need to look up the definition of a concept (He et al., 2012). More specifically, they resort to Wikipedia when they need to quickly inquire about an unknown fact or topic or for in-depth information regarding a given topic (Lim, 2009). The strategies considered under this factor are those that help reach an understanding of the information handled when studying or during other academic activities. They refer to the use of Wikipedia and online dictionaries as well as e-translators for purely apparent purposes and for a low level of information processing. The result is that students very frequently use both. More than $50 \%$ of the students frequently use online translators and more than $60 \%$ resort to Wikipedia. In this sense, the factor turns into the only one that reaches the highest level of use $(\mathrm{M}=3.65 \mathrm{SD}=.94)$ (Table 5).

Factor 5. Expansion and in-depth information. The fifth factor takes us closer to the pro-active attitude of students who are unhappy studying with only what their teachers provide. By contrast, students embark upon a richer and more independent learning process facilitated by digital technologies (video, blogs, presentations, etc.). Students like to use pre-recorded classes when preparing classes or while studying (Gorissen et al., 2012). Currently, they also rely on the slides presented by teachers (Parson et al., 2009). Our results reveal that, at some stage, $58.1 \%$ of those surveyed view videos related to the contents they are studying and $64.6 \%$ review multimedia presentations that they have found on their own accord. Students work directly on multimedia resources that have not necessarily been provided by the teacher (Table 6).

Factor 6. Monitoring and feedback. Unlike the previous factor, this one includes those strategies that pursue learning through listening. Using podcasts, students may relive

Table 4 Factorial loads, means and standard deviations of SRLTU items for the third factor, "Documentation and classification"

\begin{tabular}{llll}
\hline & Factorial load & M & SD \\
\hline $\begin{array}{l}\text { 8. I locate scientific, content-related texts in specialised data bases (Google } \\
\text { scholar, Dialnet...). }\end{array}$ & .752 & 2.99 & 1.39 \\
$\begin{array}{l}\text { 16. I use citation management tools such as RefWorks, Mendeley... when I } \\
\text { need to draft reports or essays. }\end{array}$ & .578 & 1.47 & .98 \\
\hline
\end{tabular}


Table 5 Factorial loads, means and standard deviations of SRLTU items for the factor "superficial use with limited information processing"

\begin{tabular}{llll}
\hline & Factorial load & M & SD \\
\hline $\begin{array}{l}\text { 9. I use web translators to understand content-related texts written in other } \\
\text { languages }\end{array}$ & .695 & 3.45 & 1.29 \\
$\begin{array}{l}\text { 32. I resort to Wikipedia or any other online dictionary when I need to clarify a } \\
\text { content-related topic or concept. }\end{array}$ & .550 & 3.85 & 1.15 \\
\hline
\end{tabular}

master classes with the opportunity to listen to them on more than one occasion whilst they take and check their notes. Consequently, this leads to good learning results (McKinney et al., 2009; Scutter et al., 2010). Also, academic success rates increase if students create their own audio productions, given the fact that they are involved in transforming and communicating or sharing information with others (Heilesen, 2010). Considering the massive volume of information available on the web, such presentations are a perfect complement to the information received (Hew, 2009). Based on the above, the factor is made up of those strategies that, in Zimmerman's model, respond to the review of recorded information and memorisation, which feed mainly off podcasts. However, limited use is made of all these strategies. Therefore, $84.5 \%$ of students have never downloaded podcasts for playback when studying and $75.8 \%$ have not recorded themselves for self-examination (Table 7).

Factor 7. Personal management. The strategies grouped together in this factor refer to student time and information management: the need to have immediate access to the most recently published information in sources of interest, to count on the material produced by teachers to help them when studying, to solve proposed academic activities in the most efficient and attractive manner possible and to distribute the time available for this and studying. Once again, all of the strategies included in this factor have a very low level of use: $73.1 \%$ of the students have never syndicated to electronic sources and $63.7 \%$ have never or hardly ever organised their agenda using management software (Table 8).

Factor 8. Self-evaluation. Self-evaluation is a relevant portion in the SRL process as it encourages one to ponder his/her own learning (Ibabe and Jauregizar, 2010). This is the case to such a point that it has been considered one of the central strategies in the last SRL phase. Zimmerman defined it as such and Pintrich considered it among the metacognitive strategies, more specifically follow-up. Self-evaluation is the activity through which students verify their own level of learning, as they must carry out self-correction exercises or digital tests on line. Despite its importance for SRL, it is not widely used by students $(\mathrm{M}=1.85 \mathrm{SD}=.86)$ : $90.2 \%$ of the students never or hardly ever practiced

Table 6 Factorial loads, means and standard deviations of SRLTU items for the factor "expansion and in-depth information"

\begin{tabular}{llll}
\hline & Factorial load & M SD \\
\hline $\begin{array}{l}\text { 31. I follow Youtube video channels where there are videos related to the topics } \\
\text { I'm studying. }\end{array}$ & .783 & 1.97 & 1.27 \\
5. When studying, I search for content-related videos on Youtube, Vimeo... & .643 & 2.83 & 1.28 \\
33. I follow blogs by experts who publish content-related work. & .521 & 2.04 & 1.27 \\
3. When studying, I look for multimedia, content-related presentations (Slideshare, & .444 & 2.95 & 1.27 \\
Prezi...). & & & \\
\hline
\end{tabular}


Table 7 Factorial loads, means and standard deviations of SRLTU items for the sixth factor, "Monitoring and feedback"

\begin{tabular}{|c|c|c|c|}
\hline & Factorial load & M & SD \\
\hline 7. I record my own content-related podcasts to use them when I'm studying. & .676 & 1.29 & .79 \\
\hline 2. I record the teacher's presentations with my mobile device. & .668 & 1.54 & .94 \\
\hline 6. When studying, I listen to content-related podcasts found on iTunes, iVoox... & .590 & 1.24 & 67 \\
\hline $\begin{array}{l}\text { 22. When preparing a presentation, a practical exam.... I record myself using a } \\
\text { handheld device. }\end{array}$ & .430 & 1.45 & .95 \\
\hline
\end{tabular}

with simulated online exams, and even when $40.9 \%$ have at some point practiced with self-correction activities, 58.4\% make little or very little use of them (Table 9).

Factor 9. Collaborative learning. Collaborating or simply interacting with classmates is the aim of the strategies included in the last of the factors. They all correspond to a specific category of those considered in Zimmerman's (social support) model as well as Pintrich's (social resource management). Although self-regulation learning is an individual characteristic, it is no longer questionable if a student community offers an adequate environment for developing SRL (Beishuizen, 2008). This factor illustrates how certain digital technologies favour social learning, as would be the case of cloud computing technologies (Denton, 2012). Unlike the rest of the factors, two of the strategies included are of very frequent use: $74.1 \%$ of the students frequently interact with their classmates outside the classroom using instant messaging apps, and $63.4 \%$ regularly share material via the cloud for studying or working together (Table 10).

Ultimately, the factor analysis provides new aspects for organising SRL strategies as put forward by Zimmerman (1989, 1990) or Pintrich (1999a, b). Those identified have been updated with the incorporation of digital technologies on behalf of the students.

\section{What profiles could be identified among students based on their use of self-regulation strategies with technology?}

The description of each of the factors proves that some of the technology-based SRL strategies are more frequent than others among university students. Herein, the descriptions of the two antagonistic student profiles identified evidence that Andalusian university students do not use technology-based SRL strategies in the same manner. It is noteworthy that a large number of young people implement limited strategies without a high level of usage.

Table 8 Factorial loads, means and standard deviations of SRLTU items for the factor "personal management"

\begin{tabular}{llll}
\hline & Factorial load & M & SD \\
\hline $\begin{array}{l}\text { 19. I use programmes such as Google Calendar, EverNote... to handle my } \\
\text { academic activity agenda. }\end{array}$ & .646 & 2.23 & 1.52 \\
$\begin{array}{l}\text { 21. I download content-related material through my institution's repository of } \\
\text { learning objects (RODAS, RiUMA, etc.) or from open learning resource }\end{array}$ & .579 & 2.22 & 1.45 \\
libraries such as Universia. & & & \\
$\begin{array}{l}\text { 27. I use Really Simple Syndication (RSS) feeds to receive updated information } \\
\text { about topics I am interested in. }\end{array}$ & .533 & 1.51 & 1.01 \\
$\begin{array}{l}\text { 30. I use specific apps (such as scientific calculator Kaljulilo, Whiteboard Lite...) } \\
\text { to solve problems and exercises included in the subjects. }\end{array}$ & .454 & 1.82 & 1.23 \\
\hline
\end{tabular}


Table 9 Factorial loads, means and standard deviations of SRLTU items for the eighth factor, "Self-evaluation"

\begin{tabular}{llll}
\hline & Factorial load & M & SD \\
\hline $\begin{array}{l}\text { 24. I look for content-related, self-evaluation exercises online and I use them } \\
\text { to prepare for exams. }\end{array}$ & .700 & 2.36 & 1.28 \\
$\begin{array}{l}\text { 23. I create online exam samples (ExamTime, Google Forms...) and I share them } \\
\text { with my classmates when preparing exams. }\end{array}$ & .515 & 1.35 & .82 \\
\hline
\end{tabular}

The first profile characterises students with a greater level of self-regulation learning and the use of technologies (see Fig. 2). They represent 84 students, which is $11.86 \%$ of the respondents. Of these, $65.5 \%$ are female, and $59.5 \%$ are between 21 and 25 years of age while $17.9 \%$ are under 20 . They stand out because they have the greatest mean frequency of implementation in all the factors, including those with a low level of use as in the case of sharing information and monitoring and feedback. They are students who use a variety of technologies for discussion, request help from peers, exchange material and collaborate with classmates when studying or preparing classwork. They are more familiar with handling instant messaging $(\mathrm{IM})$ apps $(\mathrm{M}=4.78 \mathrm{SD}=.47)$ but they do not forsake videoconference tools $(\mathrm{M}=3.43 \mathrm{SD}=1.31)$ for communication. They frequently use online translators, $(\mathrm{M}=4.12 \mathrm{SD}=.97)$, encyclopaedias and dictionaries $(\mathrm{M}=4.11 \mathrm{SD}=1.00)$ to help process information that they do not understand. They are used to searching the web for multimedia resources such as videos $(\mathrm{M}=4.10$ $\mathrm{SD}=1.05)$ and presentations $(\mathrm{M}=4.02 \mathrm{SD}=1.04)$ that allow them to expand and delve into the information received in the classroom.

The second profile, on the other hand, refers to students with a lower level of use of self-regulation learning strategies involving technologies (see Fig. 2). This group includes 238 students, which corresponds to $33.62 \%$ of the respondents. Of these, $62.2 \%$ are between 21 and 25 years of age. This group of students shows an intermediate level regarding the use of strategies for the superficial use of information and collaborative learning factors. Most of them actively use instant messaging apps to communicate with their classmates $(\mathrm{M}=4.27 \mathrm{SD}=1.07)$. They are frequent Wikipedia users $(\mathrm{M}=3.41 \mathrm{SD}=1.21)$.

\section{Discussion}

This study adopts the theoretical models regarding self-regulation learning developed by Zimmerman and Pintrich for the interpretation of the use that Andalusian university students make of digital technologies to favour learning. We have moved away from limiting the focus of this work on the type of technologies used in their learning processes, whether this is due to individual initiatives, independently of classroom

Table 10 Factorial loads, means and standard deviations of SRLTU items for the factor "Collaborative learning"

\begin{tabular}{|c|c|c|c|}
\hline & Factorial load & M & SD \\
\hline 4. I share material with my classmates using Dropbox, Google+ & .754 & 3.72 & 1.22 \\
\hline 11. I produce collaborative work using tools such as wikis, Google Drive... & .753 & 3.44 & 1.38 \\
\hline $\begin{array}{l}\text { 12. I interact outside the classroom with classmates using apps (WhatsApp, } \\
\text { Line...) and we exchange information, solve doubts, etc. }\end{array}$ & .597 & 4.59 & .82 \\
\hline $\begin{array}{l}\text { 13. I communicate with my classmates via videoconference (Skype, } \\
\text { Google Talk...) to solve or discuss topics related to the subjects. }\end{array}$ & .562 & 2.19 & 1.34 \\
\hline
\end{tabular}




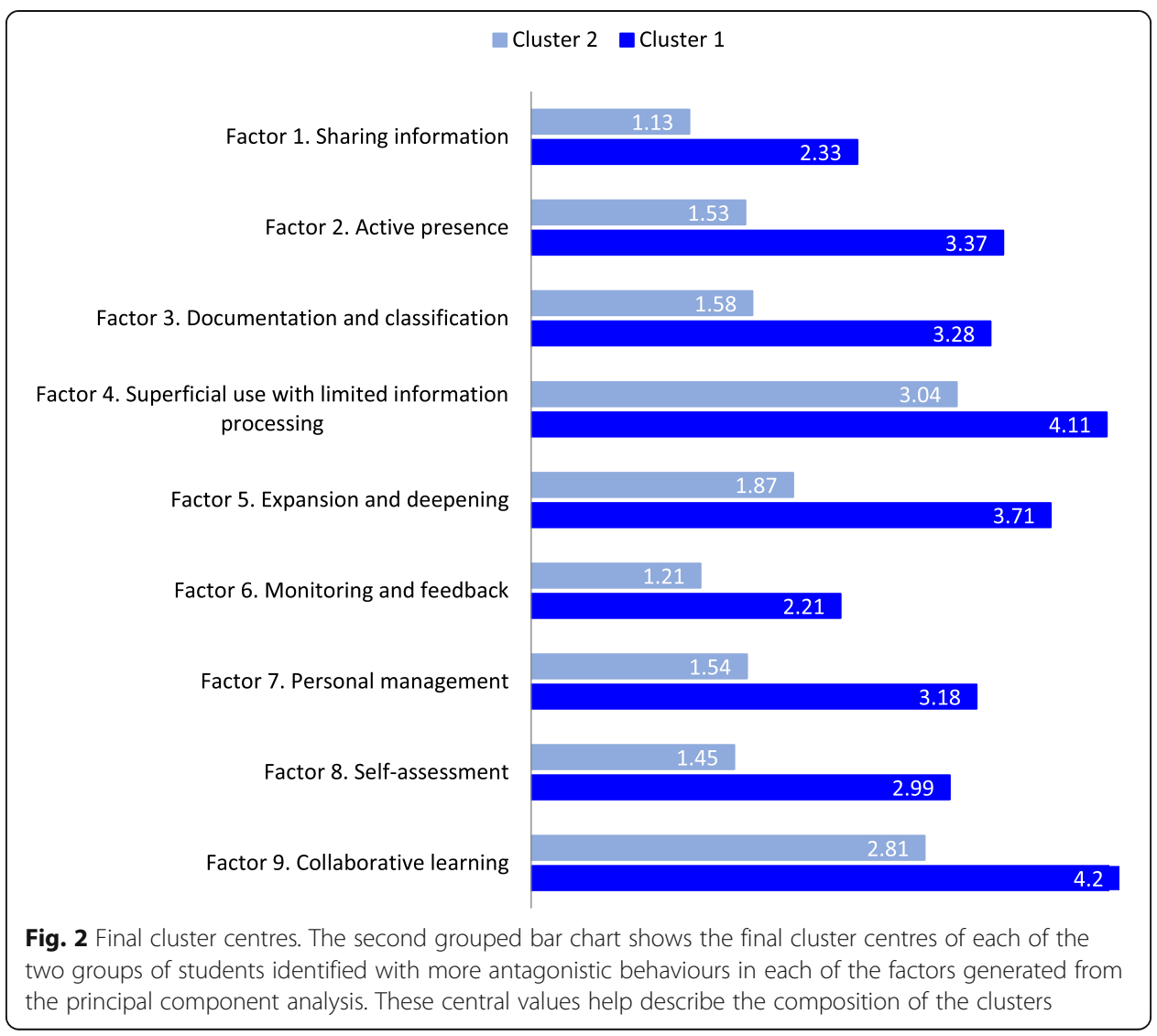

demands or the frequency with which students use these technologies. This research is more focused on determining which type of SRL strategies university students use digital technologies for.

We can state that Andalusian university students make limited use of learning technologies. Most of the technologies that we considered could be useful to assist them in studying are, in practice, excluded. Internet search engines or databases and instant communication tools are the most generalised and used continually by the respondents. These coincide with those identified by Kennedy et al. (2008) as the resources that students generally want to use in their studies. Despite the time elapsed since this work was presented, we agree with Mirriahi \& Alonzo (2015) that the type of technology that students handle for learning has remained practically unchanged over the years.

On the other hand, we maintain that university students carry out varied actions to self-regulate learning using technologies. This coincides with the conclusions reached by Chaves et al. (2016). Based on the most used technologies, the most generalized SRL strategies are those relative to social support. As shown in the cluster analysis, even the group of students with a lesser level of use of self-regulation learning strategies with technologies uses them regularly.

The selected profiles show that university students do not have a uniform behaviour when it comes to SRL and technologies. New lines of work are now open. It will be interesting to deepen into how students organize and manage their learning using technologies, and the reasons that explain the varied uses of SRL strategies with 
technologies. Observation and interviews allow us to learn and trace processes, learning dilemmas and styles among students.

According to Winne (1995), SRL is principally comprised of knowledge, beliefs and learned skills. It forms incrementally as learners engage with instructional experiences where they receive information that is useful to construct knowledge about what productive self-regulation is, and when and how it can be used. Consequently, future research should look into the individual differences regarding a learner's knowledge base about SRL, and knowledge about when and under what conditions that knowledge is engaged. Equally, we should reconsider going over at least one of the questions that Boekaerts \& Cascallar (2006) address: "What can teachers do to help students selfregulate their learning, motivation and effort?"

Upon analising the learning activities that instructors at Andalusian universities design and implement (Authors, 2015), it becomes apparent that if students do not use digital technologies to regulate their own learning, it is because teachers neither require nor encourage their use. There is no reason why students who use digital resources on a regular basis in their personal and social life should not use them when studying or learning. We therefore highlight the need for university teachers to incorporate digital technologies, because our students must learn to use the technological and conceptual tools that workers use in professional careers. Failing to do so translates into the perpetuation of the gap between industry and education (Feiman \& Buchmann, 1983): the university world and the labour and social world.

University teachers need to create learning environments that favour independent and self-regulated learning, in which students have opportunities to seek challenges, to reflect on their progress, and to take responsibility and pride in their accomplishments (Paris \& Paris, 2001). Research is appearing, not only to highlight teaching methods that can improve academic self-regulation but also to present teaching models that promote SRL using new ICTs as support (Cazan, 2013; Núñez et al., 2011).

New technologies are being incorporated into the design of intervention programs to promote SRL within the university context (Cerezo et al., 2010). For example, there are a growing number of learning designs that seek to achieve balance between selfregulated, personalised learning and scaffolding/support through the use of Web 2.0 and social software tools (McLoughlin \& Lee, 2010). Dabbagh \& Kitsantas (2012) described one of the possible pedagogical frameworks that teachers can use to demonstrate to students how to use social media to foster SRL.

If we propose to research how students become masters of their own learning processes and teachers contribute to it, we have to reconsider the methodology followed in the data collection phase of this research (Zimmerman, 2008). At the same time, we must surpass an important limitation encountered in the interpretation of our findings. Future research should consider expanding the size and diversity of the student sample, while also taking the teacher population into account.

Beyond what is presented herein, this work is useful to expand our understanding of how SRL takes place with technologies. The factor analysis used to aid the presentation of the results facilitates a way to interpret SRL strategies that is different from the models presented by Zimmerman and Pintrich. The resulting factors constitute categories that are useful to classify the set of SRL strategies that university students develop by means of technologies. Each of the factors groups together strategies that seek 
the same learning objective through pedagogical affordances of technology (information, relationship or personal management, monitoring, etc.). Following the models by Zimmerman and Pintrich only allows us to recognize SRL strategies based on technologies that respond to the aspect of social support or management of resources (social) and self-assessment or follow-up.

Consistent with our results, previous studies have evidenced that different technological tools (e.g., collaborative and communication tools, content creation and delivery tools) supported different SRL processes (Dabbagh \& Kitsantas, 2005). In keeping with this, SRL strategies need to be explained in a way that differs from the time when the technological component was not included to facilitate the task (Lai \& Gu, 2011).

\section{Conclusions}

This work addresses a set of SRL strategies that university students may implement using digital technologies. The strategies identified are consistent with what has been pointed out in the research literature. These strategies range from the simplest activities, such as reading, classifying, using or sharing information, to others with a higher level of intentionality and cognitive complexity, such as monitoring, selfassessment or personal management.

Of them all, we highlight a group of strategies that show the appropriation of digital technologies for a more connected learning model. We are referring to those strategies that we have called "active presence". These prove university students' interest in sharing and exchanging their own digital contents, creating opinions, etc. Ultimately, this demonstrates that young people need to have a personal presence on the network and favours collaborative learning. Students project their learning well beyond the physical academic space to be able to learn with their fellow classmates by using digital technologies.

Therefore, the results show a university student profile that usually fails to consider it necessary, or lacks adequate training, to incorporate digital technologies into their own academic learning process. Students make limited use of SRL strategies with technologies. They state that the digital technologies they use have more to do with simple activities such as searching, storing or sharing information. These activities, although necessary for the learning process, are limited when not complemented with others that support understanding, monitoring or self-assessment of the actual student throughout the learning process.

As a final conclusion, university teachers must favour self-regulation of learning, offer the students the opportunities to discover the usefulness of digital technologies and foster their incorporation into the actual learning process.

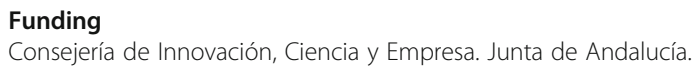


Consent for publication

Not applicable

Competing interests

Not applicable

\section{Publisher's Note}

Springer Nature remains neutral with regard to jurisdictional claims in published maps and institutional affiliations.

Received: 30 April 2017 Accepted: 31 October 2017

Published online: 17 November 2017

\section{References}

Marcelo, C., Yot, C., \& Mayor, C. (2015). University Teaching with Digital Technologies. Comunicar, 23(45), 117-124. doi: 10.3916/C45-2015-12

Baggetun, R., \& Wasson, B. (2006). Self-regulated learning and open writing. European Journal of Education, 41(3/4), 453-472. doi:10.1111/j.1465-3435.2006.00276.x.

Barnard Brak, L., Lan, W. Y., \& Paton, V. O. (2010). Profiles in self-regulated learning in the online learning environment. International Review of Research in Open and Distance Learning, 11(1), 61-80.

Beishuizen, J. (2008). Does a community of learners foster self-regulated learning? Technology, Pedagogy and Education, 17(3), 183-193. doi:10.1080/14759390802383769.

Beishuizen, J., \& Steffens, K. (2011). A conceptual framework for research on self-regulated learning. In R. Carneiro, P. Lefrere, K. Steffens, \& J. Underwood (Eds.), Self-regulated learning in technology enhanced learning environments, (pp. 3-19). The Netherlands: Sense Publishers.

Bennett, S. J., Maton, K. A., \& Kervin, L. K. (2008). The "digital natives" debate: A critical review of the evidence. British Journal of Educational Technology, 39(5), 775-786. doi:10.1111/j.1467-8535.2007.00793.x.

Bernacki, M. L., Aguilar, A. C., \& Byrnes, J. P. (2011). Self-regulated learning and technology- enhanced learning environments: An opportunity-propensity analysis. In G. Dettori, \& D. Persico (Eds.), Fostering self-regulated learning through ICT, (pp. 1-26). Hersey, PA: IGI Global Publishers.

Boekaerts, M., \& Cascallar, E. (2006). How far have we moved toward the integration of theory and practice in selfregulation? Educational Psychology Review, 18(3), 199-210. doi:10.1007/s10648-006-9013-4.

Cazan, A. M. (2013). Teaching self-regulated learning strategies for psychology students. Procedia. Social and Behavioral Sciences, 78, 743-747. doi:10.1016/j.sbspro.2013.04.387.

Cerezo, R., Núñez, J. C., Rosário, P., Valle, A., Rodríguez, S., \& Bernardo, A. B. (2010). New media for the promotion of selfregulated learning in higher education. Psicothema, 22(2), 306-315.

Chaves, E., Trujillo, J. M., \& López, J. A. (2016). Acciones para la autorregulación del aprendizaje en entornos personales. Píxel-Bit. Revista de Medios y Educación, (48), 67-82. doi:10.12795/pixelbit.2016.148.05.

Corrin, L., Bennett, S., \& Lockyer, L. (2010). Digital natives: Everyday life versus academic study. In Paper presented at the 7th International Conference on Networked Learning. Aalborg: Denmark.

Dabbagh, N., \& Kitsantas, A. (2005). Using web-based pedagogical tools as scaffolds for self-regulated learning. Instructional Science, 33(5), 513-540. doi:10.1007/s11251-005-1278-3.

Dabbagh, N., \& Kitsantas, A. (2012). Personal learning environments, social media, and self-regulated learning: A natural formula for connecting formal and informal learning. Internet and Higher Education, 15(1), 3-8. doi:10.1016/j.iheduc. 2011.06.002.

Dabbagh, N., \& Kitsantas, A. (2013). Using learning management systems as Metacognitive tools to support selfregulation in higher education contexts. In R. Azevedo, \& V. Aleven (Eds.), International handbook of Metacognition and learning technologies, (pp. 197-211). New York: Springer.

Dahlstrom, E., Walker, J. D., \& Dziuban, C. (2013). ECAR study of undergraduate students and information technology. Louisville, CO: EDUCAUSE Center for Analysis and Research.

Deepwell, F., \& Malik, S. (2008). On campus, but out of class: An investigation into students' experiences of learning technologies in their self-directed study. ALT-J, Research in Learning Technology, 16(1), 5-14. doi:10.3402/rlt.v16i1.10881.

Denton, D. W. (2012). Enhancing instruction through constructivism, cooperative learning, and cloud computing. TechTrends, 56(4), 34-41. doi:10.1007/s11528-012-0585-1.

Dilek-Kayaoglu, H. (2014). Information-seeking behavior of undergraduate, graduate, and doctoral students: A survey of Istanbul University, Turkey. In J. N. Gathegi, Y. Tonta, S. Kurbanoğlu, U. Al, \& Z. Taşkın (Eds.), Challenges of information management beyond the cloud, (pp. 123-136). Berlin: Springer.

Ebner, M., Lienhardt, C., Rohs, M., \& Meyer, I. (2010). Microblogs in higher education. A chance to facilitate informal and process-oriented learning? Computers \& Education, 55(1), 92-100. doi:10.1016/j.compedu.2009.12.006.

Feiman, S., \& Buchmann, M. (1983). Pitfall of experience in teacher preparation. Michigan: Institute for Research on Teaching Retrieved from http://files.eric.ed.gov/fulltext/ED237504.pdf.

Gallardo, E., Marqués, L., \& Bullen, M. (2015). Students in higher education: Social and academic uses of digital technology. RUSC. Universities and Knowledge Society Journal, 12(1), 25-37. doi:10.7238/rusc.v12i1.2078.

Gao, F., Luo, T., \& Zhang, K. (2012). Tweeting for learning: A critical analysis of research on microblogging in education published in 2008-2011. British Journal of Educational Technology, 43(5), 783-801. doi:10.1111/j.1467-8535.2012.01357.x.

Gorissen, P., van Bruggen, J., \& Jochems, W. (2012). Students and recorded lectures: Survey on current use and demands for higher education. Research in Learning Technology, 20, 297-311. doi:10.3402/rlt.v20i0.17299.

Gosper, M., Malfroy, J., \& McKenzie, J. (2013). Students' experiences and expectations of technologies: An Australian study designed to inform planning and development decisions. Australasian Journal of Educational Technology, 29(2), 268-283. doi:10.1234/ajet.v29i2.127. 
He, D., Wu, D., Yue, Z., Fu, A., \& Vo, K. T. (2012). Undergraduate students' interaction with online information resources in their academic tasks. A comparative study. ASLIB Proceedings, 64(6), 615-640. doi:10.1108/00012531211281715.

Heilesen, S. B. (2010). What is the academic efficacy of podcasting? Computers \& Education, 55(3), 1063-1068. doi:10. 1016/j.compedu.2010.05.002.

Hew, K. F. (2009). Use of audio podcast in K-12 and higher education: A review of research topics and methodologies. Educational Technology Research and Development, 57(3), 333-357. doi:10.1007/s11423-008-9108-3.

Ibabe, I., \& Jauregizar, J. (2010). Online self-assessment with feedback and metacognitive knowledge. Higher Education, 59(2), 243-258. doi:10.1007/s10734-009-9245-6.

Imler, B., \& Hall, R. A. (2009). Full-text articles: Faculty perceptions, student use, and citation abuse. Reference Services Review, 37(1), 65-72. doi:10.1108/00907320910935002.

Jones, C., Ramanau, R., Cross, S., \& Healing, G. (2010). Net generation or digital natives: Is there a distinct new generation entering university? Computers \& Education, 54(3), 722-732. doi:10.1016/j.compedu.2009.09.022.

Kennedy, G. E., Judd, T. S., Churchward, A., Gray, K., \& Krause, K. L. (2008). First year students' experiences with technology: Are they really digital natives? Australasian Journal of Educational Technology, 24(1), 108-122. doi: 10.14742/ajet.v24i1.1233.

Kingsbury, M. (2015). Encouraging independent learning. In H. Fry, S. Ketteridge, \& S. Marshal (Eds.), A handbook for teaching and learning in higher education: Enhancing academic practice, (pp. 169-179). New York: Routledge.

Kitsantas, A. (2013). Fostering college students' self- regulated learning with learning technologies. Hellenic Journal of Psychology, 10, 235-252

Kitsantas, A., \& Dabbagh, N. (2011). The role of web 2.0 technologies in self-regulated learning. New Directions for Teaching and Learning, (126), 99-106. doi:10.1002/tl.448.

Lai, C., \& Gu, M. (2011). Self-regulated out-of-class language learning with technology. Computer Assisted Language Learning, 24(4), 317-335. doi:10.1080/09588221.2011.568417.

Lai, C., Wang, Q., \& Lei, J. (2012). What factors predict undergraduate students' use of technology for learning? A case from Hong Kong. Computers \& Education, 59(2), 569-579. doi:10.1016/j.compedu.2012.03.006.

Lim, S. (2009). How and why do College students use Wikipedia? Journal of the American Society for Information Science and Technology, 60(11), 2189-2202. doi:10.1002/asi.21142.

Littlejohn, A., Margaryan, A., \& Vojt, G. (2010). Exploring students' use of ICT and expectations of learning methods. Electronic Journal of e-Learning, 8(1), 13-20.

Lorenzo Romero, C., Alarcón del Amo, M. C., \& Gómez Borja, M. A. (2014). Learning styles and web technology use in business and economics university students. Procedia. Social and Behavioral Sciences, 141, 1281-1290. doi:10.1016/j. sbspro.2014.05.221.

Margaryan, A., Littlejohn, A., \& Vojt, G. (2011). Are digital natives a myth or reality? University students' use of digital technologies. Computers \& Education, 56(2), 429-440. doi:10.1016/j.compedu.2010.09.004.

McKinney, D., Dyck, J. L., \& Luber, E. S. (2009). iTunes university and the classroom: Can podcasts replace professors? Computers \& Education, 52(3), 617-623. doi:10.1016/j.compedu.2008.11.004.

McLoughlin, C., \& Lee, M. J. W. (2010). Personalised and self-regulated learning in the web 2.0 era: International exemplars of innovative pedagogy using social software. Australasian Journal of Educational Technology, 26(1), 28-43.

Mirriahi, N., \& Alonzo, D. (2015). Shedding light on students' technology preferences: Implications for academic development. Journal of University Teaching \& Learning Practice, 12(1), 1-14.

Ning, H. K., \& Downing, K. (2015). A latent profile analysis of university students' self-regulated learning strategies. Studies in Higher Education, 40(7), 1328-1346. doi:10.1080/03075079.2014.880832.

Nosko, A., \& Wood, E. (2011). Learning in the digital age with SNSs: Creating a profile. In B. White, I. King, \& P. Tsang (Eds.), Social media tools and platforms in learning environments, (pp. 399-418). Berlin: Springer-Verlag.

Núñez, J. C., Cerezo, R., Bernardo, A., Rosário, P., Valle, A., Fernández, E., \& Suárez, N. (2011). Implementation of training programs in self-regulated learning strategies in Moodle format: Results of a experience in higher education. Psicothema, 23(2), 274-281.

Panadero, E., \& Alonso Tapia, J. (2014). How do students self-regulate? Review of Zimmerman's cyclical model of selfregulated learning. Anales de Psicología, 30(2), 450-462. doi:10.6018/analesps.30.2.167221.

Paris, S. G., \& Paris, A. H. (2001). Classroom applications of research on self-regulated learning. Educational Psychologist, 36(2), 89-101. doi:10.1207/S15326985EP3602_4.

Parson, V., Reddy, P., Wood, J., \& Senior, C. (2009). Educating an iPod generation: Undergraduate attitudes, experiences and understanding of vodcast and podcast use. Learning, Media and Technology, 34(3), 215-228. doi:10.1080/17439880903141497.

Pintrich, P. R. (1999a). Taking control of research on volitional control: Challenges for future theory and research. Learning and Individual Differences, 11(3), 335-354. doi:10.1016/S1041-6080(99)80007-7.

Pintrich, P. R. (1999b). The role of motivation in promoting and sustaining self-regulated learning. International Journal of Educational Research, 31(6), 459-470. doi:10.1016/50883-0355(99)00015-4.

Pintrich, P. R. (2004). A conceptual framework for assessing motivation and self-regulated learning in college students. Educational Psychology Review, 16(4), 385-407. doi:10.1007/s10648-004-0006-X.

Prensky, M. (2001). Digital natives, digital immigrants. On the Horizon, 9(5), 1-6. doi:10.1108/10748120110424816.

Schneckenberg, D., Ehlers, U., \& Adelsberger, H. (2011). Web 2.0 and competence-oriented design of learning. Potentials and implications for higher education. British Journal of Educational Technology, 42(5), 747-762. doi:10.1111/j.1467-8535.2010.01092.x

Scutter, S., Stupans, I., Sawyer, T., \& King, S. (2010). How do students use podcasts to support learning? Australasian Journal of Educational Technology, 26(2), 180-191. doi:10.14742/ajet.v26i2.1089.

Swanson, J. A., \& Walker, E. (2015). Academic versus non-academic emerging adult college student technology use. Technology, Knowledge and Learning, 20(2), 147-158. doi:10.1007/s10758-015-9258-4.

Valentín, A., Mateos, P. M., González Tablas, M. M., Pérez, L., López, E., \& García, I. (2013). Motivation and learning strategies in the use of ICTs among university students. Computers \& Education, 61, 52-58. doi:10.1016/j.compedu. 2012.09.008. 
Valle, A., Núñez, J. C., Cabanach, R. G., González, J. A., Rodríguez, S., Rosário, P., Cerezo, R., \& Muñoz, M. A. (2008). Selfregulated profiles and academic achievement. Psicothema, 20(4), 724-731.

Vivian, R. (2011). University students' informal learning practices using Facebook: Help or hindrance? In R. Kwan, C. McNaught, P. Tsang, F. Lee Wang, \& K. Cheong Li (Eds.), Enhancing learning through technology. Education unplugged: Mobile technologies and web 2.0, (pp. 254-267). Berlin: Springer.

Vrocharidou, A., \& Efthymiou, I. (2012). Computer mediated communication for social and academic purposes: Profiles of use and university students' gratifications. Computers \& Education, 58(1), 609-616. doi:10.1016/j. compedu.2011.09.015

Winne, P. H. (1995). Inherent details in self-regulated learning. Educational Psychologist, 30(4), 173-187. doi:10.1207/ s15326985ep3004_2.

Winters, F. I., Greene, J. A., \& Costich, C. M. (2008). Self-regulation of learning within computer-based learning environments: A critical analysis. Educational Psychology Review, 20(4), 429-444. doi:10.1007/s10648-008-9080-9.

Wong, K., Kwan, R., Leung, K., \& Wang, F. L. (2012). Exploring the potential benefits of Facebook on personal, social, academic and career development for higher education students. In S. K. S. Cheung, J. Fong, L. F. Kwok, K. Li, \& R. Kwan (Eds.), Hybrid learning, (pp. 253-264). Berlin: Springer.

Zimmerman, B. J. (1989). A social cognitive view of self-regulated academic learning. Journal of Educational Psychology, 81(3), 329-339.

Zimmerman, B. J. (1990). Self-regulated learning and academic achievement: An overview. Educational Psychologist, 25(1), 3-17.

Zimmerman, B. J. (1998). Developing self-fulfilling cycles of academic regulation: An analysis of exemplary instructional models. In D. H. Schunk, \& B. J. Zummerman (Eds.), Self-regulated learning. From teaching to self-reflective practice, (pp. 1-19). New York: The Guilford Press.

Zimmerman, B. J. (2008). Investigating self-regulation and motivation: Historical background, methodological developments, and future prospects. American Educational Research Journal, 45(1), 166-183. doi:10.3102/ 0002831207312909

Zimmerman, B. J. (2009). Theories of self-regulated learning and academic achievement: An overview and analysis. In B. J. Zimmerman, \& D. H. Schunk (Eds.), Self-regulated learning and academic achievement, Theoretical Perspectives (pp. 1-38). New York: Routledge.

Zimmerman, B. J., \& Martinez Pons, M. (1986). Development of a structured interview for assessing student use of selfregulated learning strategies. American Educational Research Journal, 23(4), 614-628. doi:10.3102/ 00028312023004614.

Zimmerman, B. J., \& Moylan, A. R. (2009). Self-regulation: Where metacognition and motivation intersect. In D. J. Hacker J. Dunlosky, \& A. C. Graesser (Eds.), Handbook of Metacognition in education, (pp. 299-315). New York: Routledge.

Zimmerman, B. J., \& Schunk, D. H. (2011). Self-regulated learning and performance. In B. J. Zimmerman, \& D. H. Schunk (Eds.), Handbook of self-regulation of learning and performance, (pp. 1-12). New York: Routledge.

\section{Submit your manuscript to a SpringerOpen ${ }^{\circ}$ journal and benefit from:}

- Convenient online submission

- Rigorous peer review

Open access: articles freely available online

- High visibility within the field

- Retaining the copyright to your article 